\title{
TOURIST DESTINATION AS AN OBJECT OF RESEARCH OF SOCIAL AND ECONOMIC GEOGRAPHY
}

\section{Nilufar Kh. Komilova}

Department of Economic and Social Geography

National University of Uzbekistan named after Mirzo Ulugbek

100174, 4 University Str., Tashkent, Republic of Uzbekistan

nkomilova75@mail.ru

\section{Mashrab R. Usmanov}

Department of Geography and Fundamentals of Economics Jizzakh State Pedagogical Institute named after Abdulla Qodiri

mashrabusmonov79@gmail.com

\section{Nasiba I. Safarova}

Department of Geography and methods of its teaching

Tashkent state pedagogical University named after Nizami

100183, the Avenue Bunyodkor, 27 Tashkent, Republic of Uzbekistan nasibasafarova1975@gmail.com

\section{Aybibi E.Matchanova}

Department of Geodesy, cartography,geography,Natural Sciences faculty,Urgench State University. named after Kh.Alimdjan str.,Urgench city.Khorezm,Uzbekistan.221000.

E-mail: aybibi79@mail.ru

\section{Gulrukh I. Murtazaeva}

student of the National University of Uzbekistan named after Mirzo Ulugbek

100174, 4 University Str., Tashkent, Republic of Uzbekistan

gulruxmurtazayeva8@gmail.com

\section{ABSTRACT:}

This article describes the basic concept of "tourist destination" in the tourism system, its content and essence, the definition given by various scholars, that destination is a geographical region with a certain attractiveness for tourists. The definitions of the concept of "destination" proposed by the authors in scientific sources are based on the division into four groups according to their important aspects: territorial, economic, social, administrative. While the assessment of the concept of "tourist destination" in the regional context is based primarily on the criterion of "dependence" on the specific geographical location of the region, economically tourist destination is considered as a specific destination for tourists and is considered an economic category. one is that there is a tourist demand.

While the social aspect is the interpretation of a tourist destination as a specific socio-geographical place, it is conceived that any system is governed by forces of a natural nature as a subject of management that characterizes the concept of a tourist destination. The article also touches on the concept of "tourism industry" and the work on the development of tourism in Uzbekistan today.

Keywords: Destination, "tourist destination", "tourism industry", tourist complex, image of restination, travel and visits, tourist services and products

Article Received: 18 October 2020, Revised: 3 November 2020, Accepted: 24 December 2020

\section{Introduction}

In the tourism system, "tourist destination" is one of the key concepts, which at the regional level is particularly evident in the interaction and interdependence of this system with the external socio-economic macro-environment.
Destination is a key element of the tourist system and has been interpreted in various literatures as a geographical area with certain boundaries. From another point of view destination is a geographical region, a region with a certain attractiveness for tourists. In general, in 
order to be called a "destination", it must meet the following basic requirements:

- Availability of the necessary service complex for the reception of tourists;

- Availability of attractive objects and places of interest to tourists (one of the main factors of competition between destinations is attractiveness, which should be a unique aspect to attract tourists to the destination area);

- The availability of information systems is a necessary "tool" of destination in the tourism market.

\section{Methodology of research}

In the domestic and foreign literature, the concept of "tourism industry" directly refers to the activities of tourism enterprises, hotels and restaurants, travel agencies, manufacturers and sellers of tourist goods, but in a broader sense to describe the whole set of enterprises that directly and indirectly meet tourism needs. There is also the concept of "destination".

A tourist destination with various amenities, facilities and services to meet the diverse needs of tourists can also be described as a center (territory). In other words, tourist destination includes the most necessary and crucial aspects of tourism that are necessary for tourists [1].

The tourist destination region is one of the most important in the tourist system, because tourist destinations and their image attract tourists, justify the visit, thus activating the whole tourist system. The English translation of the word "destination" - "Destination" - means "place, destination." The term "tourist destination" was coined by Leiper in the mid-1980s.

Currently, according to NS Ibragimov, the term "Destination" is expressed in the Uzbek language by the terms "determination" or "tourist destination" [2].

According to H.M. Mamatkulov, destination is a territory or address that offers certain services, meets the needs of tourists, meets the requirements of its purpose [3].
According to N.Komilova, destination is a certain geographical area with certain boundaries, which can attract tourists and meet their needs [4].

According to EG Alyonova, a tourist destination is a place that, like physical, political or market boundaries, has a real or imaginary boundary, attracting an influx of tourists due to its attractive (attractive) opportunities. All existing destinations of historical and cultural value in the world are flourishing at the expense of funds received from tourists. In the organizational and economic mechanism of formation of tourist destination, the main purpose of the subjects of management is to create, support or change the desires, opinions of consumers of the region's tourism products. ${ }^{1}$

According to AF Gorokhov, tourist destination should be understood as a set of tourist products that are concentrated, rapidly produced and consumed in time and space [6].

Definitions of the term "destination" in foreign and Russian scientific sources are given in the following table (Table).

As can be seen from the definitions given in Table 1, the concept of "tourist destination" has been interpreted differently by different authors. The result is a blurry and abstract landscape that prevents clear comprehension. In our opinion, it would be expedient to divide the definitions of the concept of "destination" proposed by the authors in scientific sources into four groups according to their important aspects: territorial, economic, social, administrative. $^{2}$

1 Komilova, N.Kh., Mukhammedova, N.J., Abdalova, Z.T., Nazarov, M.I., \& Kurbanov, P.R.(2020). Separate aspects of the demographic situation in Uzbekistan and its assessment in geographical context. International Journal of Psychosocial Rehabilitation. 24(08) 6773-6792.

2 Komilova, N.K., Mukhammedova, N.J., TOJIEVA, Z.N., Nazarov, M.I., \& Egamberdiyeva, U.T.(2019) Territorial Definitions of Population Mortality in Uzbekistan ASTRA SALVENSIS, YEAR VII, Supplement no. 1, 619-641 
Table Definitions of the concept of "destination" proposed in scientific sources

\begin{tabular}{|c|c|}
\hline Authors & Definitions \\
\hline \multicolumn{2}{|r|}{ In foreign scientific sources } \\
\hline V.Altxof & $\begin{array}{l}\text { A clearly defined location or target area. Destinations can include, for } \\
\text { example, out-of-town excursions, leisure facilities, communes, regions, } \\
\text { federal lands, Germany, the European Union, etc. }\end{array}$ \\
\hline K.Kasper & The place that "crystallizes the tourist offer" \\
\hline Leyper & Attractive geographical area for tourists \\
\hline P.Pirs & $\begin{array}{l}\text { A place that leaves a variety of impressions, experiences and emotions for } \\
\text { tourists }\end{array}$ \\
\hline \multicolumn{2}{|r|}{ In Russian scientific sources } \\
\hline M.A.Morozov & $\begin{array}{l}\text { An area that meets the needs of the tourist and offers a certain set of } \\
\text { services that meet its requirements for transportation, catering, } \\
\text { entertainment and so on. In this case, the author first distinguishes the } \\
\text { main purpose of the trip as the primary destination and the stops on the } \\
\text { way to the primary destination as secondary destinations [10]. }\end{array}$ \\
\hline T.A.Sebekina & $\begin{array}{l}\text { A place with real or abstract boundaries (physical, political, geographical, } \\
\text { market): the country, province, island, etc. where tourists come for a } \\
\text { specific purpose }\end{array}$ \\
\hline A.Y.Ryabuxa & $\begin{array}{l}\text { A destination can be an area or facility that has tourist facilities, is sold by } \\
\text { service providers, and is chosen by the tourist for his or her visit }\end{array}$ \\
\hline S.S.Nikolayev & $\begin{array}{l}\text { A tourist destination is a place (place, region, city, village, amusement } \\
\text { park) chosen as a destination for a particular socio-geographical, specific } \\
\text { tourist or whole segment of tourist demand. It has all the necessary } \\
\text { facilities, organizations, accommodation, service facilities and } \\
\text { entertainment infrastructure [13]. }\end{array}$ \\
\hline
\end{tabular}

* Source: Created by the authors.

Territorial aspect. In terms of territory, the assessment of the concept of "tourist destination" is based primarily on the criterion of "dependence" on the specific geographical location of the region. Most authors associate the destination with a certain place in the space that cannot be changed and tourists are directed in that direction (P.Pierce, Leiper, M.A.Morozov, S.S.Nikolaev, T.A.Sebekina). According to the definition of A.Yu. Ryabukha, in addition to the location, as a destination can also be considered buildings that are not related to a specific area, that is, in the opinion of the author, the location of the destination may change. In the descriptions of V.Althof and K.Kaspar the question of territorialspatial connection of tourist destination remains unclear.

Economic aspect. In the descriptions of V.Althof, Leiper, P.Pierce, T.A.Sebekina, the tourist destination is considered as a certain destination visited by tourists and it is considered as an economic category, while K.Kaspar, M.A.Morozov, S. One of the important features characterizing the destination in the descriptions 
of S.Nikolayev, A.Yu.Ryabukha is the tourist demand. Consequently, in these definitions of tourist destination they are understood not only as an attractive area for tourists, but primarily as their own consumption value and as an object of market relations and a tourist product.

In addition, in the descriptions of SS Nikolaev and MA Morozov, the presence of tourist infrastructure (accommodation, catering, entertainment, vehicles) is also mentioned as an important feature. Consequently, it is becoming clear that a tourist destination not only plays the role of a commodity or product, but also a specific economic space.

Social aspect. In the definition of SS Nikolaev, tourist destination is interpreted as a certain sociogeographical place, that is, in the opinion of the author, the place of tourist destination is also a place of life of the local community. In the descriptions of other authors, the social aspect remains undefined. ${ }^{3}$

Management aspect. The concept of "tourist destination" as a subject of descriptive governance is conceived as the control of any system by forces of a natural nature. However, in this case, we are taking a person as a subject of management, and the tourist destination is evaluated from the same point of view in terms of management. In our opinion, a feature that allows us to conclude that there is a management aspect in the definition of the concept of "tourist destination" is its evaluation as a market object. Thus, in the descriptions of K.Kaspar, M.A.Morozov, S.S.Nikolayev and A.Yu.Ryabukha, tourist destination is interpreted as a controlled system.

The reasons for the different interpretations of the concept of "tourist destination" are primarily the complexity, dynamics and contradictions of the events

\footnotetext{
${ }^{3}$ Mamatkulov X.M. Glossary of terms and phrases related to the service sector. $-\mathrm{T} .:$ "ECONOMYFINANCE", 2010. - 398 p.
}

described by it, so its definition will be the basis for further analysis.

The study of the concept of "tourist destination" as an economic category and its definition add to the list of important features, on the one hand, the criterion of "tourist demand" and, as a result, the destination is considered a commodity. objects and the existence of relationships between them ". These "economic" criteria make up two different types of tourist destinations that can be combined within a single destination. Consequently, the definition of the concept of "tourist destination" in terms of different "economic" criteria will vary according to the objectives of the study.

1. In our opinion, the full definition of the concept of "tourist destination" is a specific area, address, place of residence or historicalpilgrimage sites visited by citizens who do not live permanently at this address and do not belong to the local population for the purpose of tourist travel (tourist trip, excursion).

2. Each destination has its own characteristics, but the following four common features need to be highlighted:

3. Destination consists of the following components: attraction (natural resources or manmade, i.e. something that encourages a tourist to travel); amenities (accommodation, catering, entertainment and other services in the service sector, such as retail and medical facilities, barbershops, currency exchange offices, banks).

4. In our opinion, the full definition of the concept of "tourist destination" is a specific area, address, place of residence or historicalpilgrimage sites visited by citizens who do not live permanently at this address and do not belong to the local population for the purpose of tourist travel (tourist trip, excursion).

5. Each destination has its own characteristics, but the following four common features need to be highlighted:

\section{Results and discussion}


Destination consists of the following components: attraction (natural resources or manmade, i.e. something that encourages a tourist to travel); amenities (accommodation, catering, entertainment and other services in the service sector, such as retail and medical facilities, barbershops, currency exchange offices, banks).

Destination services and facilities are used not only by tourists, but also by others: including locals and employees of this destination.

The study found that four main external factors have a significant impact on the image of a tourist destination:

- the general image or prestige of the region (country, region, city) that geographically determines the destination;

- external influences: natural disasters, terrorism, radical socio-economic changes, etc .;

- communication strategy of destination in target markets;

- Demand and preferences of potential tourists in the target markets.

The image of a tourist destination is closely related to the overall image of the region, which includes socio-economic, business, political, legal, investment and other aspects.

Tourist destination in Uzbekistan has sufficient development potential. This situation is marked by the presence of a large number of unique natural objects (lakes, mountain peaks, forests on the banks of rivers) and a rich cultural and historical heritage. There are more than 4,000 architectural, artistic and historical monuments of different cultural and historical periods in our country, most of which are included in the UNESCO World Heritage List. ${ }^{4}$

According to the results of the study, the image of Uzbekistan as a sustainable developing republic in Central Asia has all the opportunities for the further development of tourist destinations.

\footnotetext{
${ }^{4}$ Komilova, N.Kh., Karshibaeva, L.K., Egamberdiyeva, U.T., Abduvalieva, Z. L., \& Allanov, Sh.Q.(2020) Study of nozogeographic situation and its study on the basis of sociological survey. Indian Journal of Forensic Medicine and Toxicology. 14(3), 2093-2098.
}

Tourist destinations in Uzbekistan, which has great tourist potential, now require the development of a model of interaction between suppliers and consumers.

As noted above, the modern general law of urban development is associated with a complete or partial change in the specialization in which its economy is formed, the functions performed by the city in the system of national distribution of labor. At the same time, the city is objectively affected by the processes of formation of a new specialty, which allows to effectively address the scale of socio-economic problems in the new conditions of the regional economy. Accordingly, the types of activities that should be the "destinations" of economic and social development of the city in the future for the city of Jizzakh will begin to develop more rapidly. In today's conditions, one of such "destinations" is the existing tourist complex in Jizzakh.

Local enterprises and organizations of the city tourist complex are an integral part of the socio-economic potential of the city and have a significant impact on the strategic choice of the city, ie the structure of future functions of the city, its main directions and goals in social and economic spheres. At the same time, depending on the strategic choice of the city, the policy of development of its tourist complex will be formed.

In this regard, it is necessary to study the main factors and patterns that occur within and outside the urban tourism sector and provide sustainable trends and directions of these changes. However, identifying internal and external factors as well as trends may not be sufficient conditions to formulate a strategy.

These factors should be combined with the results of the analysis of the existing tourist potential of the city and the forecasting and analytical materials of tourism enterprises with proposals for "inclusion" in the package of urban tourism products. This method of strategic analysis defines the use of the laws of tourism development in order to identify and study the 
processes of socio-economic development of the city.

The information obtained during the analysis phase is key in the development of the target block. Goals and objectives determine the direction of the planning process. In this case, the goals and objectives are associated with both marketing activities and the internal processes of operation and development of urban tourism.

In the current situation, the following structure of the strategic plan for the development of tourism in Jizzakh can be proposed: summary section; a section summarizing the results of the analysis of the socio-economic situation in the urban tourism sector; a section disclosing strategic goals and strategies for achieving the set goals; Department of proposals, activities and programs for the implementation of strategic goals of tourism development.

We express the essence of the issue of forming a consolidated section of the strategic plan for the development of urban tourism and the main requirements to its content. The development of such a section consists of a generalization of the materials of other departments in such a way that they can be included in the consolidated strategic plan of socio-economic development of the city.

Addressing such an important issue of strategic planning as the development of a strategic plan for the development of the urban tourist complex, of course, requires a very serious methodological and organizational-economic support of the planning process. This is due to the need for large-scale analytical and design work and requires the involvement of not only the relevant departments of the city administration, but also scientists and specialists of various professions, representatives of the private business and public sectors of tourism, the local population.

The classification of any science or applied area is of great social importance. Because it is through classification that any human activity acquires a meaning and essence. Tourism is no exception. Usually, tourism is classified according to its various indicators. For example, tourists participating in tourism can be classified on the basis of dozens of indicators such as social status or age, duration or seasonality of tourism, where tourists come from, purpose or environmental awareness and culture. The acquisition of any classification factor or indicator in the tourist classification is carried out in a way that depends on the goals and objectives of the classifier, professional skills, level of knowledge, socioeconomic capabilities. ${ }^{5}$

The branding concept of tourist destination The concept of regional branding was first introduced to science in 2002 by Simon Anholt. Prior to that, space marketing was studied by Philip Kotler, Seppo Rainisto (Seppo Rainisto) and others as a category. Territorial or location marketing is used to identify specific areas (e.g., free-economic, industrial areas), cities, countries, or tourist destinations, and to study competition for residents and tourists, as well as investors. Continuous, holistic, systematic, large-scale marketing activities aimed at changing the image can be recognized as an important support of place or area marketing. In this case, the communication policy of marketing and its public relations support play a leading role as a marketing tool [9].

The interpretation of tourism as a nonprofit form of marketing aimed at shaping the image and development of tourism destinations at the national and regional levels reveals the essence of marketing policy in the field of tourism. The essence of tourist recreation is its identity with the functions of tourism, its social role in society. Areas such as destination branding and its image strategy are considered as special branches of modern marketing in the formation of regional marketing or regional branding concepts.

\footnotetext{
${ }^{5}$ Komilova, N.Kh., Hudayberganova, R.T, Murtazaev, I.B., Abdinazarova, H.O., \& Madaminov, Z.H. (2019). Economic and Geographic Problems of Improvement of Industrial Sectors and Local Structure of Uzbekistan. Journal of Advanced Research in Law and Economics, 10( 6 (44)), 1916-1928.
} 
The term destination means "destination" in the international tourism dictionary.

The term destination was first used by Thomas Cook as a tourist center (1840). The city of Lamfboro in England is recognized as the first destination center in the world. The concept of destination is inextricably linked with the concept of tourist and recreational center and is used in practice as a synonym. The tourist center is a convenient place consisting of infrastructure facilities that can attract tourists, consisting of unique tourist and recreational resources. Recognized by the World Tourism Organization, this official phrase refers to "the time physically spent by a visitor in a place they have visited for at least one night". That is, destination is a set of travel products consisting of services related to the satisfaction of needs, such as recreation, entertainment, overnight consumption, consumed during a day trip. "Space" in its natural (material) latitude as a destination constant; visitor; tunash; market; competitiveness; get an impression; image; convenience of location; tourist resources; attraction; tourist services; consists of elements such as a tourist product. (Rome Conference of the UN WTC 1969) [3]. Thus, the primary task of marketing and its communication policy in the field of tourism is to form a positive image of the axiological and cultural constants of tourist destination, such as city, landscape, museum, transport, ethnos, SVT (ie, Community Based Tour). ${ }^{6}$

The main purpose of marketing activities aimed at shaping the image of the destination is to create a positive image in the field of recreation, tourist pleasure and new impressions, as well as in the field of health and healing, professional business, hospitality and other areas. consists of a shift. The participant of the event, who seeks opportunities to meet their needs using the unique

\footnotetext{
${ }^{6}$ Komilova, N. K., Haydarova, Ş. A., Xalmirzaev, A. A., Kurbanov, S. B., \& Rajabov, F. T. (2019). Territorial Structure of Agriculture Development in Uzbekistan in Terms of Economical Geography. Journal of Advanced Research in Law and Economics, 10(8 (46)), 2364-2372.
}

tourist services as a tourist subject - that is, the image of the place (recognition, recognized positive axiological and other spiritual and cultural values) formed in the pre-trip impressions of the tourist in choosing a tourist destination. plays a decisive role.

Everything that can be the purpose of the trip is considered a tourism object and is done depending on the consistent operation of three main components such as destination (address), tourist organization (non-profit) and tourism enterprise. During the period established for tourists, the object of consumption is mastered in connection with travel and visits, and the level of satisfaction of all needs is determined by the usefulness of products and services (consumption efficiency). It is this delicacy that plays an important role in determining the level of satisfaction of the specific needs of travelers, as well as in shaping the image of the destination. The following elements can also be considered as factors that shape the image, ie enhance the emotional experiences of the traveler: emotional experiences at night in different conditions; participation in the production and consumption of tourist goods, enjoyment of other situations, the uniqueness of the geographical environment in which the trip takes place; extremely high quality of the means of labor used (hotels and historical and cultural centers, transport, etc.).

The proposed tourist services are divided into destination clusters across regions. Some types of services (information, mediation, etc.) are received by tourists from the place of residence, other types (transport, information, etc.) - during travel, other types of services (food, accommodation, entertainment, treatment, etc.) .k.s) in a special place. In our opinion, it is expedient to study all the external environmental factors that shape the image of the destination into four groups: - the historically formed general image or prestige (recognized reputation) of the geographical destination, such as country, administrative region, city, specific tourist center. (The state of Uzbekistan itself has a historical 
image as a product name or tourist destination). external influences such as natural disasters, terrorism, socio-economic crisis and other negative situations. - destination market-oriented communication strategy. - Motivation of potential tourists to the target market, the degree of inclination. According to a number of researchers, the image of a tourist destination is a set of personal opinions about all the factors in the composition of the destination, formed within the framework of advertising and information from various sources.

The increased level of objective consumption of services offered as a tourist object guarantees the image of the destination. Hence, the image of destination is a description formed among the public about its attractiveness to attract potential consumers and its advantages that distinguish it from other addresses. Researchers divide the image of destination into organically and artificially formed species [7].

Organic (emotional) image is an impression of a tourist about a certain destination formed under the influence of natural factors related to internal experiences within the framework of impressions and experiences gained during his direct participation. An artificial image is a collection of various forms of information created by tourism enterprises in the framework of marketing communication activities aimed at forming public opinion about a particular tourist center in order to attract tourists. ${ }^{7}$

An important part of regional image marketing is tourism destination branding, which plays an important role in developing the marketing strategy of the destination and as a support in the formation of the image of the destination. In many cases - the brand phrase - is used as a synonym for a brand or - a trademark. It is known that the trademark is the intellectual property of companies and is protected by law.

7 Goroxov A.F., Shubaeva V.G. Tourist destination: dryness, structure and conditions of its socio-economic adaptation to the needs of the market. - SPb .: GUEF, 2005.
The term "brand" means "brand" when translated directly from English. According to the American Marketing Association, "a brand is a unique name, phrase, or other unique feature or combination of a seller or group of sellers that distinguishes or identifies the goods and services of other sellers and services. means emblems".

In today's economy, a "brand" is a communicator that regularly connects producers with consumers. Branding is a technology for creating a combination of informal relationships and trust based logos based on consumer experiences that enhances the marketing opportunities of relationships. With the help of brands, manufacturers not only disseminate information to the environment about the unique features of their products, but also ensure the sustainability of their business by increasing customer satisfaction.

For consumers, the brand serves as a guide on how to save their time while reducing the level of risk of market conditions in choosing the most suitable among competing brands and firms. From the second half of the twentieth century, new directions in the use of the brand began to emerge, such as regional branding, personal branding, political branding. Brands are becoming an important attribute of people's daily lives and the subject of scientific research. The emergence and evolution of brand formation goes back a long way. The presence of special stamps in archeological evidence found in ancient Rome, Egypt, and India indicates that the stamp was formed long ago as a social attribute. (In the territory of Uzbekistan, the history of the brand dates back to the distant past, as evidenced by special marks on archeological artifacts, special marks left by artisans in the finds. written in memoirs on our history about his voice throughout). ${ }^{8}$

${ }^{8}$ Sebekina T.A. Formation of a complex of tourist services destinations (on the first Kamchatka): author. dis. ... cand. econ. science. - M .: 2006. - 22 p. 
In tourism, the destination brand consists of images formed in the imagination and impressions of consumers. The branding concept of tourist destination is the process of moving creative ideas in the target market from the main values and resources of the region in sound, graphic, animated and other image-creating means. Once a consumer's relationship to a particular region and its resources (goods and services) is formed, these ideas materialize - the brand has a real value.

The following principles play an important role in creating the branding concept of tourist destination: - establishment of general and separate tourism missions in the region; identification of target markets and groups of potential consumers; - assessment of the resource value of the destination; - The functioning of the region as a socio-economic entity and the formation of the principles of development and regulation; In the process of building a brand concept and preparing for the implementation of a brand strategy, all the factors that shape the brand, such as tourism or tourism destinations, the unique features of tourist centers are systematically studied step by step [9].

According to the results of the study, recommendations will be made to change or improve the current status of the destination brand. In addition to the above measures in the formation of the brand concept, procedures and guidelines will be developed for the implementation of the brand strategy, as well as the use of all its components, such as logos, slogans, trademarks. Creating a brand concept for a particular tourist destination requires an approach based on the same fundamental principles as in other areas of communication: Simplicity, mobility and cost-effectiveness of communication channels and supports; Availability and universality of application opportunities in all target markets; Identity with tourism motivation; Completeness, integrity of the brand impressions expected by the consumer; The humanistic aspect of tourism activity and the predominance of the socio-ethical concept of marketing. In addition, the brand or logos that are distributed in order to evoke human emotions in the visualization process of the destination brand are required to be organized on the basis of a specific stylistic approach.

\section{Conclusion}

In conclusion, it should be noted that the support of the brand concept of marketing based on the creation of a material and technical base that provides the infrastructure of the tourism cluster, improves the production of tourism services and products, helps to increase the attractiveness and competitiveness of the destination image., the popularity of the destination increases.

\section{References}

[1] Komilova, N.Kh., Mukhammedova, N.J., Abdalova, Z.T., Nazarov, M.I., \& Kurbanov, P.R.(2020). Separate aspects of the demographic situation in Uzbekistan and its assessment in geographical context. International Journal of Psychosocial Rehabilitation. 24(08) 6773-6792.

[2] Komilova, N.K., Mukhammedova, N.J., TOJIEVA, Z.N., Nazarov, M.I., \& Egamberdiyeva, U.T.(2019) Territorial Definitions of Population Mortality in Uzbekistan ASTRA SALVENSIS, YEAR VII, Supplement no. 1, 619-641

[3] Mamatkulov X.M. Glossary of terms and phrases related to the service sector. $-\mathrm{T}$.: "ECONOMY-FINANCE", 2010. - 398 p.

[4] 4. Komilova, N.Kh., Karshibaeva, L.K., Egamberdiyeva, U.T., Abduvalieva, Z. L., \& Allanov, Sh.Q.(2020) Study of nozogeographic situation and its study on the basis of sociological survey. Indian Journal of Forensic Medicine and Toxicology. 14(3), 2093-2098.

[5] Komilova, N.Kh., Hudayberganova, R.T, Murtazaev, I.B., Abdinazarova, H.O., \& Madaminov, Z.H. (2019). Economic and Geographic Problems of Improvement of 
Industrial Sectors and Local Structure of Uzbekistan. Journal of Advanced Research in Law and Economics, 10( 6 (44)), 19161928.

[6] Komilova, N. K., Haydarova, Ş. A., Xalmirzaev, A. A., Kurbanov, S. B., \& Rajabov, F. T. (2019). Territorial Structure of Agriculture Development in Uzbekistan in Terms of Economical Geography. Journal of Advanced Research in Law and Economics, $10(8$ (46)), 2364-2372.

[7] Goroxov A.F., Shubaeva V.G. Tourist destination: dryness, structure and conditions of its socio-economic adaptation to the needs of the market. - SPb .: GUEF, 2005.

[8] Sebekina T.A. Formation of a complex of tourist services destinations (on the first Kamchatka): author. dis. ... cand. econ. science. - M .: 2006. - 22 p.

[9] Aaker.D, Yoxamshteyner E. Brand leadership is a new concept of branding. M: Izd-vo dom Grebennikova, 2003 .-380p. 